\title{
TAX EVASION IN MONTENEGRO - THE FORMS OF MANIFESTATION AND MEASURES OF SUPPRESSION
}

\section{Aleksandra Knežević}

Student,

Singidunum University, Belgrade, Serbia
Correspondence:

Aleksandra Knežević

e-mail:

aleksandra.knezevic.16@singimail.rs

\begin{abstract}
:
When Montenegro became an independent state, the main goals were enabling tax policy to function in a way that would meet the standards of the European Union and enabling the state to become financially stable. The business strategies of the Tax Administration refer to zero tolerance rate towards the black economy and the application of a rigorous penal policy. A very important determinant of tax payment is tax morale - how much the taxpayer is willing to pay taxes voluntarily. The citizens of Montenegro are also involved in the fight against black economy through the application of "Be responsible, it depends on you. Black economy 0\%", citizens report irregularities in the field of black economy. In the last five years, this project has shown very good results, a large number of fines have been imposed and half of the fines have been invested in projects of social importance.
\end{abstract}

Keywords:

tax evasion, black economy, taxpayer, crime.

\section{INTRODUCTION}

Tax evasion is a form of intentional complete or partial evasion of taxes, contributions and other duties, and giving false information about the acquired income in such a way that is criminally punishable. State authorities in Montenegro are often misled about the economic strength of taxpayers because in certain situations the taxpayer does not report income from performing a certain activity to the tax authorities. Tax evasion in Montenegro is manifested through avoiding taxes and contributions, evasion of profit tax, avoiding tax which is determined on the basis of tax returns, fraud with input and output VAT (value added tax) (Institut sertifikovanih računovođa Crne Gore, 2019).

Forms of tax evasion in the countries of the European Union and other countries in the region have great similarities with the forms of tax evasion in Montenegro. Although it is considered that the forms of tax evasion differ at first glance due to different tax legislation in Montenegro, the fact is that they have common features. A large number of countries like Montenegro are fighting tax evasion related to payments, i.e. payments of cash from offshore bank accounts and phantom companies.

Cases of tax evasion are detected and suppressed with the help of the following institutions: the Tax Administration, the Directorate for Inspection Affairs, the Special State Prosecutor's Office, the Police Administration, and the Agency for the Prevention of Corruption and other state institutions. In order to successfully implement the fight against tax evasion, it is necessary to coordinate administrative procedure, cooperation between the competent authorities, as well as the use of data at their disposal. 
The Tax Administration performs the following tasks: controlling taxpayers with the help of inspection supervision, compiling reports on performed controls and issuing misdemeanour orders if necessary. The solutions established in the Information System of the Tax Administration, the database on taxpayers and the information obtained from other state bodies, play a significant role in the selection of taxpayers for inspection. The system of data exchange with foreign the Tax Administrations is being established. Due to highly developed Information System of the Tax Administration, tax authority can easily access the information of a taxpayer and thus check whether the taxpayer is settling stated obligations (contributions, VAT, profit). The most efficient procedure is the inspection of complete control of a certain taxpayer, according to which the tax authority can establish whether the taxpayer has accurately calculated and presented its obligations in the last five years, i.e. since the last inspection.

Montenegro implements various types of measures, the most important being the involvement of citizens in the fight against black economy. The campaign that began in 2014 and is called "Be responsible, it depends on you. Black economy 0\% "is underway within the project "Involvement of citizens in the fight against black economy". This project is designed with the intention of providing more efficient and better communication between citizens and state institutions. A website and an Android application through which citizens can anonymously get involved in the fight against black economy have been created. Citizens anonymously point out to irregularities in the field of undeclared work, non-issuance of fiscal invoices, violation of consumer rights, etc. Due to significant participation of citizens in pointing out irregularities in the field of black economy and action of inspection bodies, after four months of the campaign "Be responsible", citizens pointed out over 1,200 irregularities in the field of informal economy, and inspection bodies imposed fines of over 400,000 euros. By the decision of the Government, half of the amount of fines imposed was directed to the financing of projects of general social importance, which are proposed and supported by the citizens themselves. The "Be Responsible" campaign is still active and citizens are significantly involved in the fight against the black economy (Poreska uprava, 2014).

\section{LITERATURE REVIEW}

In the group of criminal offenses against business operations as well as payment transactions, tax and fiscal criminal offenses are singled out in the Criminal Law of Montenegro. The main criminal offense from this group is the offense of tax and contribution evasion (Official Gazette of Montenegro, 2019).
Jovašević (2006) presented tax crimes, especially tax and contribution evasion, as the behaviour of individuals and groups, i.e. legal entities, which directly or indirectly endanger the financial interests of the community by violating regulations and therefore causing great damage to the fiscal system.

Milošević (2005) states that the payment of taxes objectively means the confiscation of a part of the income or property, which reduces the economic strength of the taxpayer and can lead to changes in his social position. It is natural for a taxpayer to think about how to minimize his financial obligation to the state.

Journal of the Institute of Certified Accountants of Montenegro (2018) states that tax evasion occurs as:

- Complete tax evasion relating to the case where the taxpayer avoids paying the tax liability in full, and

- Incomplete tax evasion means that the taxpayer partially avoids paying the appropriate obligation by concealing important facts

An important determinant of paying taxes is tax morale. It is considered that the willingness of taxpayers to pay taxes voluntarily leads to a lower probability of tax evasion. High level of tax morale means high quality of public goods and services, greater trust in the state and reduction of corruption (Arsić, Bisić \& Randjelović, 2017).

The perpetrator of the criminal offense of tax and contribution evasion may be a taxpayer, legal representative or persons who file a tax return on his behalf and for his account; persons who compile final and periodic accounts of the company, keep business books and a person who only formally performs business activity on behalf of another person. According to Article 264 of the Criminal Law, Montenegro provides fines and legal penalties for any person who intends to avoid the following: taxes, contributions or other required duties in whole or partially; anyone who gives false information about: legally acquired income, objects or other facts that are of influence for determining such obligations. Prescribed imprisonment and fine depend on the amount of evaded obligation and payment, and can amount to a maximum of eight years in prison if the amount of the stated obligation exceeds 100,000 euros (Official Gazette of Montenegro, 2011).

In the fight for more successful implementation of tax discipline, various preventative and punitive measures are applied. Reducing the tax burden to a reasonable level also plays an important role in the prevention of illegal tax evasion, thus mitigating the factors that contribute to increasing the intensity of tax resistance (International tax avoidance and evasion, 1981). 
Adopted in December 2019, the Decree on the manner and organization the state administration operations, made the the Tax Administration of Montenegro an independent body within the Ministry of Finance. The Business Strategy of the Tax Administration states that the primary direction of the Tax Administration is zero tolerance regarding black economy while respecting the principles of transparency, non-selectivity and application of rigorous penal policy, with the aim of reducing it to a level that will not endanger the healthy part of the economy (Poreska uprava, 2019).

In 2011, the Tax Administrations of Montenegro, Serbia, Slovenia, and Bosnia and Herzegovina signed a cooperation agreement in order to exchange data in a more productive way, prevent tax evasion and reduce black economy. The agreement ensures preventing black economy and tax evasion, which are problems of all countries in the region, as well as cooperation since no the Tax Administration can work on its own in times of globalization, when cooperation is needed at all levels.

In the scientific paper "Towards changes in the tax system in Montenegro", the authors conclude that taxes and tax systems will are described as a set of complicated rules that often even legislators cannot clearly interpret in certain practical situations. All this leads to great confusion among taxpayers, increases costs for both the state and citizens, and in some ways justifies both of them to be inefficient in looking for culprits (Belgić, Subić \&Ahmetović 2017).

The Ministry of Finance is planning to establish a Sector for Tax Police by the act on internal organization and systematization of the the Tax Administration, which will perform tasks related to: fighting against tax evasion, organized crime, fighting against black economy, coordination of activities with other authorities in order to suppress money laundering, corrupt practices in the economy, tax crimes and economic crime. These plans are presented in the business strategy of the Tax Administration for the period from 2014 to 2019.

\section{METHODOLOGY}

Statistics on tax evasion in Montenegro are not available to the public. Therefore, a survey in which 105 citizens of Montenegro participated (invitation was sent on 125 e-mail addresses) was conducted in the first half of 2020. The survey was in the form of a Google questionnaire, through which Montenegrin citizens answered questions via the Internet.

A total of 105 respondents participated, 53 respondents were employed, 38 unemployed and 14 students.

The survey consisted of five questions:

- Have you been in a situation not to receive an invoice when purchasing goods or services?

- Have you ever worked without being registered?

- Would you report to the authorities if you did not receive a fiscal invoice?

- Do you think that the penal measures implemented by Montenegro are effective in combating tax evasion?

- How would you rather report tax evasion (if you decided to take that step), through the "Be Responsible" website or through the Tax Administration Call Centre?

Research results are presented in the next chapter.

\section{RESULTS AND DISCUSSION}

\section{Have you been in a situation not to receive an invoice when purchasing goods or services?}

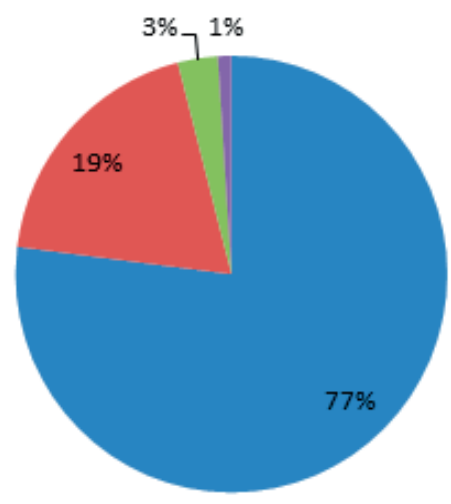

$$
\begin{aligned}
& \text { Yes } \\
& \text { No } \\
& \text { Really rare } \\
& \text { Sometimes }
\end{aligned}
$$


Based on 105 respondents in the survey, 77\% answered that they were in a situation where they did not receive a fiscal invoice when purchasing goods or services. This result is unsatisfactory because not issuing a fiscal invoice represents an illegal profit for the seller. The non-issuance of a fiscal invoice by taxpayers shows that their business is illegal and means non-disclosure of turnover and tax evasion. Penalties in Montenegro for non-issuance of fiscal invoices range from 3,800 to 10,000 euros for a legal entity, and the minimum fine for an entrepreneur is 1,000 euros.

\section{Have you ever worked without being registered?}

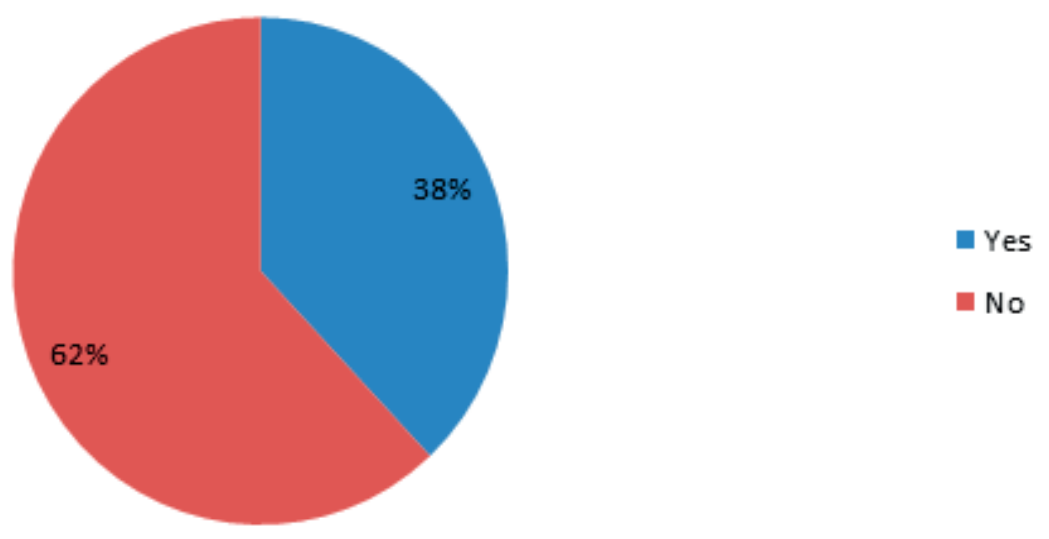

Graph 2. Have you ever worked without being registered?

In this graph it is shown that $62 \%$ of 105 respondents answered that they were not in a situation to work and not be registered. Although the situation is considered better than in previous years, that number is still high.
Undeclared work is most evident during the summer tourist season, when labour force arrives from countries in the region.

\section{Would you report to the authorities if you did not receive a fiscal invoice?}

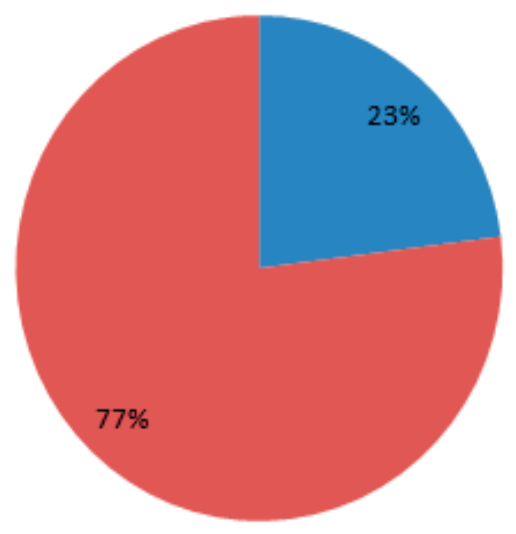

- Yes

no

Graph 3. Would you report to the authorities if you did not receive a fiscal invoice?

It is necessary to inform citizens particularly about the importance of fiscal accounts. When a consumer takes a fiscal bill, it means that he thus protects his rights as a consumer (gets a guarantee of product quality and the right to a return claim). In addition, it contributes to state budget increase and prevents money from going into the black zone. As many as $77 \%$ of respondents answered that they would not have reported to the competent authorities if they had not received a fiscal invoice. 


\section{Do you think that the penal measures implemented by Montenegro are effective in combating tax evasion?}

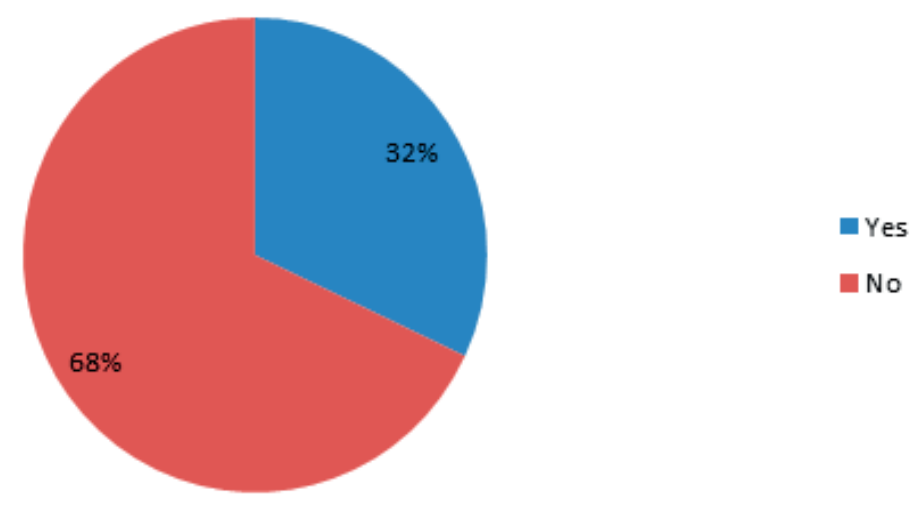

Graph 4. Do you think that the penal measures implemented by Montenegro are effective in combating tax evasion?

$68 \%$ of respondents believe that punitive measures implemented by Montenegro are not effective in combating tax evasion. It is obvious that citizens do not trust in the tax system and penal policy in combating tax evasion. If we were to go back to the previous chart and see that $77 \%$ of respondents would not report not receiving a fiscal bill, there is a clear correlation with this chart. Citizens doubt the penal policy and believe that the report will not improve the situation because the punitive measures are not effective enough.

\section{How would you report tax evasion, through the call center of The Tax Administration or "Be Responsible" website?}

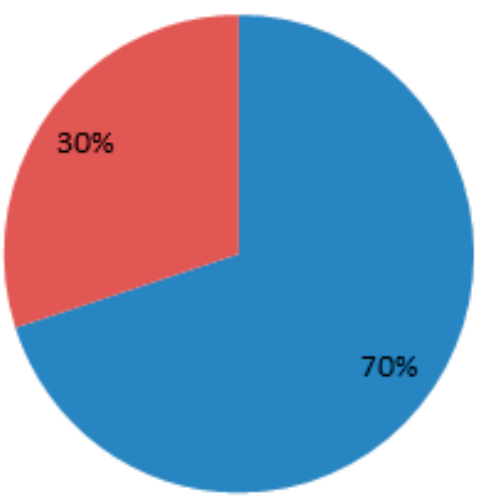

- "Be Responsible"

- Call Center

Graph 5. How would you report tax evasion, through the call centre of the Tax Administration or "Be Responsible" website?

If a person decides to report tax evasion, it would be through "Be Responsible" website. The development of IS has enabled easier communication between citizens and competent authorities. $70 \%$ of respondents would rather opt for the "Be Responsible" site because they do not want to leave any trace but seek absolute anonymity. It is assumed that citizens often have prejudice that their identity will be revealed if they call the Call Centre of the Tax Administration.
Both ways are of great importance, and it does not matter which of these two will be chosen. What is important is that there is an awareness of citizens that they should do it.

Milić (2014) claims that the black economy in Montenegro is represented in all economic activities and says that the economic activity of the tourism and hospitality sector, due to insufficient economic structures, is a suitable area for income that is not recorded, and therefore not 
subject to taxation. Problema of non-reporting accommodation capacities that are used for generating income during season, non-registering cash registers in catering facilities, non-issuance of invoices, non-registration of workers, non-payment of sojourn tax, etc. (special emphasis should be placed here).

\section{CONCLUSION}

Higher tax rates lead to a higher probability of tax evasion. It is rather natural for a taxpayer to think about minimizing the financial obligation towards the state through the activity he performs. Taxpayers are trying to increase their capital more easily and to keep most of their income by reducing the tax base on which their tax liability is calculated. There are large amounts of money and goods that move outside the taxation system in Montenegro, and the state authorities do not have the possibility to directly influence these flows.

In creating measures for more successful implementation of tax discipline, it is necessary to conduct research on the extent of tax evasion in Montenegro through various surveys of legal entities and entrepreneurs in order to illustrate this huge problem from the perspective of legal entities and entrepreneurs. Reducing the number and simplifying tax procedures would lead to a reduction in tax enforcement costs, as well as the introduction of the obligation to file tax returns electronically. In order to fight the problem of tax evasion more efficiently, the Tax Administration should pay attention to the training of employees in the Tax Administration, as well as by increasing the number of persons engaged in inspection supervision. The age structure of employees in the Tax Administration, especially tax inspectors, is a great challenge. The knowledge and skills of employees need to be transferred to new employees, for whom this will be the basis for more complicated business transactions. One of the most important preventative measures is to increase the awareness of citizens through the system of education and public information about the effects of tax evasion, because increasing tax discipline contributes to increasing the quality of services provided by the state. In order to improve financial discipline and combat tax evasion in Montenegro, it is necessary to effectively implement penal policy. Penal policy should be built so that fines are imposed in an amount that significantly exceeds the amounts of evaded tax liabilities. In order for the penal policy to be more effective, it is necessary to prohibit activity by the person who evaded taxes while performing that activity. In every country in the world, including Montenegro, a larger number of crimes in the field of tax evasion is committed than the statistics show, because a significant number of crimes remain undetected.

\section{LITERATURE}

Arsić, M., Ranđelović, S., \& Bisić, M. (2017). Poreski sistem, poreski moral i siva ekonomija, Beograd, Srbija.

Blečić, M., Žižić, M., \& Ahmetović, A. (2017). U susret promjenama poreskog sistema Crne Gore, 12(1), 19-31.

Institut sertifikovanih računovođa Crne Gore, (2019). Propisi, Available at: https://www.isrcg.org/

International tax avoidance and evasion, Compendium of documents (1981). Amsterdam: International Bureau of Fiscal Documentation, 23.

Jovašević, D. (2006). Leksikon krivičnog prava, Beograd, Službeni glasnik 3. izdanje, 1-816.

Milić, M. (2014). Fenomen sive ekonomije i njezini pojavni oblici u privredi Crne Gore, Zagreb, Hrvatska, 8(1), 65-81.

Milošević, G. (2005). Porez i izbegavanje poreza, Službeni list SCG

Official Gazette of Montenegro, 2011. Tax and contribution evasion No. 70/2003, 13/2004, 47/2006, No. 40/2008, 25/2010, 32/2011, 64/2011.

Official Gazette of Montenegro, 2019. The criminal procedure code no. 57/09, 49/10 and 35/15

Poreska uprava, Poslovna strategija Poreske uprave (2014-2019). Ministarstvo finansija, Podgorica, Crna Gora. 